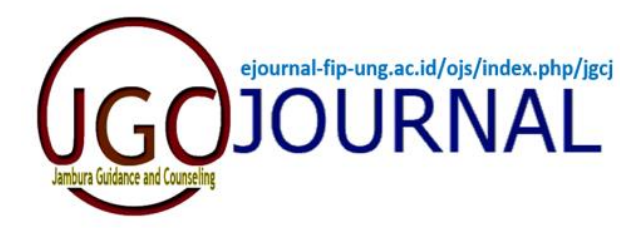

Jambura Guidance and Counseling Journal

Volume 1 Nomor 2 (November 2020), halaman 72-82

ISSN Online 2722-1628

\title{
Penerapan Bimbingan Kelompok dengan Teknik Relaksasi untuk Menurunkan Kejenuhan Belajar Pada Siswa
}

\author{
Muhammad Daud Latuconsina \\ Program Pengembangan Profesi Guru, Bimbingan dan Konseling, Universitas Negeri Makassar, Indonesia \\ muhammaddaudlatuconsina@gmail.com
}

\begin{tabular}{c|c|c}
\hline Diterima: Oktober 2020 & Disetujui: November 2020 & Dipublikasi: November 2020 \\
\hline
\end{tabular}

\begin{abstract}
Abstrak
Penelitian ini bertujuan untuk menurunkan kejenuhan belajar siswa kelas VIII MTs Negeri 1 Kota Makassar melalui bimbingan kelompok teknik relaksasi. Penelitian ini adalah penelitian tindakan kelas dengan subjek penelitian siswa kelas VIII MTs Negeri 1 Kota Makassar yang berjumlah 28 siswa. Subjek penelitian ini ditentukan dengan teknik purposive, dengan kriteria siswa yang skor kejenuhan belajarnya masuk kategori rendah dan sedang pada hasil pre-test. Metode pengumpulan data yang digunakan adalah skala kejenuhan belajar dan self report. Penelitian ini terdiri dari 2 (dua) siklus yang terdiri dari 2 (dua) tindakan. Teknik analisis yang digunakan adalah deskriptif kuantitaif. Hasil penelitian menunjukan bahwa bimbingan kelompok dengan teknik relaksasi dapat menurunkan kejenuhan belajar siswa, dilihat dari hasil data kuantitatif rata-rata skor pre-test siswa yaitu 128,75 dan menurun sebanyak 17,08 poin pada posttest I menjadi 111,67. Selanjutnya, rata-rata skor kejenuhan belajar sis wa kembali turun sebesar 14,96 sehingga didapatkan skor rata-rata pada post-test II sebesar 96,71. Secara keseluruhan penurunan skor kejenuhan belajar siswa sebesar 32,04 dengan 21 subjek berada pada kategori rendah. Jika dipersentase maka $75 \%$ subjek skor kejenuhan belajarnya berada pada ketegori rendah dan mencapai target yang ditentukan yaitu sebes ar 70\% subjek skor kejenuhan belajarnya berada pada kategori rendah.
\end{abstract}

Kata Kunci: Kejenuhan belajar, Bimbingan kelompok, Relaksasi

\begin{abstract}
This study aimed to reduce study burnout in class VIII MTs Negeri 1 Kota Makassar through relaxation. This study is a classroom action research with subjects of this study were 28 students of class VIII MTs Negeri 1 Kota Makassar. The subjects were determined by purposive technique, with the study burnout criteria of low and moderate students in the pre-test results. The data collection methods were study burnout scale, observation and interview. This study consisted of 2 (two) cycles with 2 (two) actions in every cycle. The analysis technique in this study was descriptive quantitative. The results showed that games could decrease study burnout in students, based on the results of quantitative data average pre-test score was 128.75 and decreased by 17.08 points in post-test I to 111.67. Furthermore, the average student scores dropped back by 14.96, thus the average score on post-test II was 96.71. Overall, the decline was 32.04 with 21 subjects in the low category, in percentage it reached $75 \%$, it could be concluded that it reached the target result where at least $70 \%$ of the subjects should be in the low category.
\end{abstract}

Keywords: Study burnout,Group guidance, Relaxation 


\section{PENDAHULUAN}

Pendidikan merupakan unsur penting dalam mewujudkan manusia seutuhnya, menurut UU No. 20 Tahun 2003 tentang Sistem Pendidikan Nasional, Pendidikan adalah usaha sadar dan terencana untuk mewujudkan suasana belajar dan proses pembelajaran agar peserta didik secara aktif mengembangkan potensi dirinya untuk memiliki kekuatan spiritual keagamaan, pengendalian diri, kepribadian, kecerdasan, akhlak mulia, serta ketrampilan yang diperlukan dirinya, masyarakat, bangsa dan negara. Tujuan dari pendidikan di Indonesia yakni, untuk mengembangkan potensi peserta didik agar menjadi manusia yang beriman dan bertakwa kepada Tuhan Yang Maha Esa, berakhlak mulia, sehat, berilmu, cakap, kreatif, mandiri, dan menjadi warga negara yang demokratis serta bertanggung jawab.

Upaya mewujudkan manusia yang sesuai dengan tujuan pendidikan nasional erat kaitanya dengan belajar dan proses pembelajaran. Definisi belajar sendiri adalah serangkaian kegiatan jiwa raga untuk memperoleh suatu perubahan tingkah laku sebagai hasil dari pengalaman individu dalam interaksi dengan lingkungannya yang menyangkut kognitif, afektif dan psikomotor (Syaiful Bahri Djamarah, 2011:13). Sedangkan pembelajaran menurut Sugihartono, dkk (2012: 73), merupakan kegiatan yang dilakukan untuk menciptakan suasana atau memberikan pelayanan agar siswa belajar. Perbedaan antara belajar dan pembelajaran terletak pada penekanannya. Belajar lebih menekankan pada pembahasan tentang siswa dan proses yang menyertai dalam rangka perubahan tingkah lakunya. Sedangkan pembelajaran lebih menekankan pada guru dalam upayanya untuk membuat siswa dapat belajar.

Proses belajar mewajibkan siswa untuk mengembangkan kreativitas berfikir dan meningkatkan pengetahuan sebagai upaya penguasaan materi pembelajaran, semua kewajiban itu ditempuh selama enam hari dalam seminggu dan dibeberapa daerah menerapkan lima hari selama seminggu. Tuntutan dan banyaknya aktivitas siswa sedangkan kemampuan yang dimliki siswa satu dengan yang lainya berbeda kerap kali membuat siswa mengalami stres yang tinggi. Stres yang berkepanjangan pada siswa dapat menyebabkan terjadinya kejenuhan belajar. Kejenuhan belajar merupakan salah satu faktor yang mempengaruhi tidak optimalnya proses pembelajaran. Proses pembelajaran tidak optimal dikarenakan pada saat guru memberikan pelajaran tidak mampu dimengerti dan dipahami secara maksimal ke otak siswa.

Suwarjo \& Diana Septi Purnama (2014:12), mengartikan kejenuhan (burnout) sebagai suatu keadaan keletihan (exhaustion) fisik, emosional, dan mental. Ciri-ciri individu yang mengalami kejenuhan yakni, perasaan tidak berdaya dan putus harapan, keringnya perasaan, konsep diri yang negatif dan sikap negatif. Gejala ini sering identik dengan distress, discontent, dan perasaan gagal untuk mencapai tujuan ideal.

Zuni Eka K. \& Elisabeth Christiana (2014: 2), menyatakan bahwa banyaknya aktivitas dan kegiatan diskolah, serta tuntutan-tuntutan yang ada yang harus dialami oleh siswa dapat menyebabkan siswa mengalami gejala-gejala seperti siswa mengalami kelelahan pada seluruh bagian indera, dan kurang bersemangat dalam mengikuti kegiatan belajar mengajar, timbul rasa bosan, kurang motivasi, kurang pehatian, tidak ada minat, 
serta tidak mendatangkan hasil. Dari gejala-gejala tersebut nampak bahwa siswa mengalami kejenuhan belajar.

Fenomena kejenuhan belajar pada siswa merupakan fenomena yang banyak terjadi didunia pendidikan. Terdapat beberapa studi yang mengkaji secara mendalam tentang kejenuhan belajar pada siswa. Kejenuhan belajar yang terjadi pada siswa harus mendapatkan penanganan, baik penanganan dari siswa sendiri, keluarga, lingkungan rumah maupun lingkungan sekolah. Pada lingkungan sekolah guru bimbingan dan konseling memiliki peran yang penting dalam upaya mengatasi kejenuhan belajar siswa.

Dari hasil observasi awal yang dilakukan peneliti ketika melakukan Asesmen pada tanggal 16 Agustus 2018 saat pemberian inventori siswa terlihat bosan, tertunduk dan berkata capek maupun huu yang menandakan siswa merasa jenuh dengan kegiatan belajar yang rutin dialami siswa. Selain itu, dari wawancara dengan guru BK di MTs Negeri 1 Kota Makassar menyatakan bahwa, beberapa siswa kelas VIII menunjukkan perilaku kejenuhan belajar. Perilaku-perilaku kejenuhan belajar ini ditunjukkan siswa seperti, mudah lelah seperti mengantuk bahkan tertidur di kelas, kurangnya gairah belajar, bolos sekolah, keluar masuk ruangan ketika proses belajar sedang berlangsung, merasa tidak betah di kelas, mudah marah, mudah merasa kesal tidak mampu mengerjakan tugas, tidak tertarik terhadap beberapa pelajaran, merasa menjadi orang tidak mampu dengan teman yang lain, tidak percaya diri, dan tidak puas terhadap hasil belajar.

Dari perilaku-perilaku yang ditunjukkan dari siswa tersebut, jika dibiarkan terusmenerus akan berdampak pada prestasi belajar siswa. Sehingga perlu kiranya ada solusi atau bentuk penanganan yang tepat dalam mengatasi kejenuhan belajar siswa. Oleh karena itu, Peneliti ingin melakukan penelitian dalam mengatasi masalah kejenuhan belajar siswa tersebut karena peneliti ingin siswa tetap berprestasi tanpa adanya hambatan. Selain itu, salah satu penyebab masalah kejenuhan belajar terjadi karena kurangnya motivasi dari dalam diri siswa itu sendiri. Sehingga peneliti ingin menumbuhkan motivasi siswa dan memberikan dorongan dari dalam diri siswa agar mampu mengatasi kesulitan belajar dan meningkatkan prestasinya.

Melihat hal tersebut, maka perlu dilakukan suatu penelitian ilmiah, dengan tujuan untuk menemukan sebuah alternatif pemecahan masalah dalam upaya menurunkan kejenuhan belajar siswa, agar dapat meningkatkan hasil belajar siswa. Pelaksanaan layanan bimbingan dan konseling tentunya menggunakan teori dan pendekatan tertentu antara lain psikoanalisis, behavioral, eksistensial humanistik, client center, gestalt, analisis transaksional, dan pendekatan rasional emotif (IPt. Edi Sutarjo, Dewi Arum WMP. \& Ni. Kt. Suarni, 2014). Pendekatan behavioral sebagai salah satu pendekatan yang dapat digunakan dalam layanan bimbingan dan konseling, memiliki berbagai teknik salah satunya yaitu teknik relaksasi.

Relaksasi merupakan salah satu teknik dalam terapi perilaku yang dapat digunakan individu untuk menciptakan mekanisme batin dalam diri individu dengan membentuk kepribadian yang baik, menghilangkan berbagai bentuk pikiran yang kacau akibat ketidakberdayaan individu dalam mengendalikan ego yang dimilikinya, mempermudah individu mengontrol diri, menyelamatkan jiwa, dan memberikan kesehatan bagi tubuh individu (Zuni Eka K. \& Elisabeth Christiana, 2014: 3). 
Selain pendapat di atas IPt. Edi Sutarjo, Dewi Arum WMP. \& Ni. Kt. Suarni (2014), berpandangan pula bahwa burnout yang dialami siswa dapat dikondisikan atau dapat diminimalisasi dengan tingkah laku yaitu dengan menggunakan teknik relaksasi serta dapat pula membantu meringankan kondisi tegang atau jenuh yang dialami oleh siswa. Keletihan sebagai penyebab umum terjadinya kejenuhan belajar menurut Burn yang dikutip oleh Beech, 1982 (Nursalim, 2013) menyatakan bahwa kelelahan, aktifitas mental, dan/ atau latihan fisik yang tertunda dapat diatasi lebih cepat dengan menggunakan ketrampilan relaksasi. Penelitian IPt. Edi Sutarjo, Dewi Arum WMP \& Ni. Kt. Suarni pada tahun 2014 menunjukan hasil bahwa konseling behavioral teknik relaksasi dan brain gym efektif untuk menurunkan kejenuhan belajar pada siswa kelas VIII di Sekolah Menengah Pertama. Penelitian serupa mengenai penanganan kejenuhan belajar dilakukan oleh Zuni Eka K. \& Elisabeth Christiana Cristiana, 2014 menunjukan hasil kejenuhan belajar pada siswa kelas XI Sekolah Menengah Atas dapat diturunkan dengan menerapkan kombinasi antara teknik relaksasi dan self-intruction. Berdasarkan pemikiran dan permasalahan tersebut maka tujuan dalam pelaksanaan penelitian ini adalah untuk menurunkan kejenuhan belajar melalui bimbingan kelompok dengan teknik relaksasi pada siswa kelas VIII di MTs N 1 Kota Makassar.

\section{METODE}

\section{Jenis dan Desain Penelitian}

Penelitian ini menggunakan jenis Penelitian Tindakan Kelas (PTK) dengan menggunakan desain yaitu rencana penelitian berdaur ulang (siklus) yang terdiri dari: perencanaan, pelaksanaan, pengamatan (observasi), dan refleksi.

\section{Subjek Penelitian}

Subjek dalam penelitian tindakan kelas ini adalah siswa kelas VIII MTs Negeri 1 Kota Makassar yang ditentukan menggunakan purposive sampling yang artinya subjek ditentukan berdasarkan kriteria tertentu. Kriteria tersebut adalah : 1) Siswa-siswa dengan permasalahan kejenuhan belajar, data diperoleh berdasarkan hasil pembagian angket kejenuhan belajar dan 2) Siswa yang memperoleh skor kejenuhan belajar dengan kategori tinggi dan sedang.

\section{Teknik Pengumpulan Data}

Penelitian ini menggunakan angket kejenihan belajar dalam check list, sebuah daftar dan pedoman observasi Self Report.

\section{Teknik Analisis Data}

Teknik analisis data dalam penelitian ini adalah analisis data kuantitatif. Untuk mengetahui tingkat kejenuhan belajar dengan instrumen skala, maka penentuan kategori kecenderungan dari tiap-tiap variabel didasarkan pada norma atau ketentuan kategori sebagai berikut:

1. Skor terendah) sampai dengan $(\mathrm{M}-1 \mathrm{SD})=$ Rendah 
2. $(\mathrm{M}-1 \mathrm{SD})$ sampai dengan $(\mathrm{M}+1 \mathrm{SD})=$ Sedang

3. $(\mathrm{M}+1 \mathrm{SD}$ ) sampai dengan (Skor Tertinggi) = Tinggi

Selanjutnya kategori tersebut disusun dan kemudian dianalisis secara deskriptif kuantitatif. Adapun langkah-langkah penghitungan sebelum kategorisasi sebagai berikut :

1. Menentukan skor Tertinggi dan Terendah

Skor Tertinggi $=4 \times$ Jumlah Item

Skor Terendah $=1 \times$ Jumlah Item

2. Menghitung Mean Ideal (M)

$$
\mathrm{M}=1 / 2 \text { (Skor Tertinggi }+ \text { Skor Terendah) }
$$

3. Menghitung Standar Deviasi (SD)

$\mathrm{SD}=1 / 6$ ( Skor Tertinggi - Skor Terendah

Selanjutnya kategori kejenuhan belajar tersebut akan disusun dan kemudian dianalisis secara deskriptif kuantitatif. Adapun langkah-langkah penyusunannya adalah sebagai berikut:

1. Menentukan skor tertinggi dan terendah: Skala kejenuhan belajar berisi 49 pernyataan yang masing-masing memiliki skor maksimal 4 dan skor minimal 1, sehingga total skor maksimalnya adalah 49x $4=196$, dan skor minimalnya adalah 49 x $1=49$

2. Menentukan rata-rata skor ideal: $1 / 2$ (skor tertinggi + skor terendah); $1 / 2(196+49)=$ 122,5

3. Menghitun starndar deviasi (SD); $1 / 6$ (skor tertinggi - skor terendah) ; 1/6 (196- 49) = 24,5

Skor kejenuhan belajar siswa dapat dikategorisasikan sesuai kurve normal menjadi tiga kelompok dengan interval dalam tabel 1.

Tabel 1. Kategorisasi Tingkat Kejenuhan Belajar

\begin{tabular}{ccc}
\hline Kategori & Interval & Skor Interval \\
\hline Rendah & $\mathrm{X}<(\mathrm{M}-1 \mathrm{SD})$ & Di bawah 98 \\
\hline Sedang & $(\mathrm{M}-1 \mathrm{SD}) \leq \mathrm{x} \leq(\mathrm{M}+1 \mathrm{SD})$ & $98-147$ \\
\hline Tinggi & $\mathrm{X}>(\mathrm{M}+1 \mathrm{SD})$ & Di atas 147 \\
\hline
\end{tabular}

Analisis data secara deskriptif kuantitatif dalam penelitian ini adalah memberikan penjelasan data kuantitatif secara detail yaitu dengan membandingkan hasil skor pengisian skala sebelum tindakan dan setelah tindakan yang diperoleh subjek serta menjelaskan kondisi-kondisi lain yang terjadi selama proses pemberian tindakan. Perpaduan kuantitatif dan kualitatif, sebagai yang utama digunakan kualitatif untuk menceritakan proses tindakan dan kuantitatif untuk membantu melihat terjadinya penurunan.

\section{HASIL TEMUAN}

Dalam Penelitian ini, penelitian melakukan pre-test terlebih dahulu sebelum melaksanakan tindakan dengan tujuan untuk mengukur tingkat kejenuhan belajar siswa. Pada pre-test kejenuhan belajar siswa diambil menggunakan skala kejenuhan belajar yang 
berisi 49 butir pernyataan dimana pernyataan-pernyataan tersebut telah diuji validitas dan reliabilitasnya. Setelah melakukan pre-test selanjutnya dilakukan tindakan dan kemudian dilakukan post test yaitu dengan skala kejenuhan belajar untuk mengukur tingkat kejenuhan belajar setalah dilakukan tindakan. Hasil pre-test menunjukan bahwa dari 28 Siswa, skor yang tertinggi adalah 154 dan skor terendah adalah 105 dengan rata-rata skor 128,75. Hal tersebut menunjukan bahwa kejenuhan belajar Siswa masih tergolong tinggi dan sedang.

\section{Deskripsi Hasil Pelaksanaan Tindakan}

Penelitian ini merupakan jenis penelitian tindakan kelas tentang penerapan bimbingan kelompok dengan teknik relaksasi untuk menurunkan kejenuhan belajar pada siswa kelas VIII di MTs Negeri 1 Kota Makassar yang dilaksanakan dalam 2 siklus dengan 4 kali pertemuan, diantaranya 2 kali pemberian bimbingan dan 2 kali tindakan relaksasi. Adapun rincian kegiatan sebagai berikut:

\section{a) Tindakan Siklus I}

Hasil dari tindakan pada siklus I dalam penelitian ini dapat dilihat dari pengamatan dan post-test I. Pemberian post-test $I$ dilaksanakan setelah pertemuan terakhir. Data kejenuhan belajar setelah dilakukan post-test I dari 28 Siswa, skor tertinggi 146 dan skor terendah 91. Penurunan skor kejenuhan belajar siswa setelah dilakukan post- test I.

Berdasarkan pada hasil post-test I dapat diketahui bahwa terjadi penurunan skor rata-rata dari 128,75 sebelum tindakan menjadi 111,67 setelah dilakukannya tindakan. Terdapat enam siswa yang skor kejenuhan belajarnya berada pada ketegori rendah. Jika dipresentasekan maka $21 \%$ dari seluruh subjek berada pada kategori rendah. Hasil tersebut sudah menunjukan adanya penurunan skor dari hasil pre- test. Penurunan skor rata-rata mencapai 17,07 poin atau 9\% dari skor total 196 poin. Meskipun skor rata-rata siswa masih dalam kategori sedang. Berdasarkkan hasil skor rata-rata pada siklus pertama dapat diidentifikasi bahwa relaksasi dapat menurunkan kejenuhan belajar pada siswa. Namun penurunan kejenuhan belajar pada siswa belum memenuhi kriteria keberhaslian penelitian. Oleh karena itu peneliti memutuskan untuk mengadakan siklus kedua.

\section{Hasil Self Report}

Lembar self report digunakan sebagai catatan laporan mengenai pelaksanaan relaksasi otot secara mandiri oleh siswa. Lembar tersebut memuat tentang seberapa banyak siswa melaksanakan relaksasi otot, perubahan yang dirasakan setelah melakukan relaksasi otot, dan kejadian-kejadian yang dialami siswa yang mungkin memberi pengaruh terhadap tingkat kejenuhan belajar siswa.

Peneliti memperoleh informasi bahwa rata-rata siswa melaksanakan relaksasi otot secara mandiri sebanyak 2 kali dalam jangka waktu 8 hari. Setelah melaksanakan relaksasi otot, peneliti melihat belum ada perubahan yang Nampak hanya beberapa siswa yang sudah menampakkan perubahannya. Sedangkan kejadian-kejadian yang dialami siswa kebanyakan adalah tidak bisa tenang ketika melakukan relaksasi, suara bising dan kadang bingung pada tahapannya. Berdasakan hasil self report pada siklus I ini, peneliti 
menyimpulkan bahwa siswa masih bingung dan belum bisa melakukan relaksasi secara mandiri sehingga membutuhkan bantuan.

\section{Hasil Pengamatan (Observing)}

Berdasarkan observasi pada pelaksanaan siklus 1 secara keseluruhan dapat dikatakan berjalan dengan lancar. Pada tindakan I siklus 1 diamati Siswa terlihat masih canggung dalam melaksanakan bimbingan. Tingkat antusiasme masih kurang dan siswa masih terihat mecoba meyesuaikan diri dengan kegiatan yang sedang lakukan.

Pada tindakan kedua, Siswa mulai terlihat memiliki antusiasme yang cukup tinggi. Siswa juga terlihat tidak lagi canggung dalam melaksanakan relaksasi, akibatnya relaksasi dapat berjalan dengan lancar. Pada tindakan ini terjadi hambatan pada waktu pelaksanaan, karena 15 menit dari jam bimbingan dan Siswang dipakai untuk tes harian oleh salah guru mata pelajaran. Sehingga waktu yang digunakan untuk relaksasi terbatas.

\section{Hasil Refleksi}

Refleksi dilakukan untuk mengetahui kekurangan yang ada pada pelaksanaan tindakan. Refleksi dilaksanakan berdasarkan hasil observasi selama siklus I. Ditemukan beberapa kekurangan dalam proses pelaksanan relaksasi dalam upaya menurunkan kejenuhan belajar. Namun, secara keseluruhan kegiatan pada siklus I sudah berjalan lancar karena siswa sudah memiliki antusiasme yang tinggi, dapat melaksanan intruksi dengan baik meskipun terdapat beberapa kekurangan didalamnya. Beberapa kekurangan yang ada pada siklus I yaitu :

a) Beberapa siswa masih terlihat canggung dan kurang antusias dalam mengikuti kegiatan. Hal ini terjadi karena kegiatan ini baru pertama kali mereka lakukan dan tingkat keakraban masih kurang.

b) Waktu yang digunakan untuk pelaksanaan teknik relaksasi terbatas. Untuk mengatasi kekurangan - kekurangan yang ada pada siklus I, maka dilakukan perbaikan pada siklus II, perbaikan-perbaikan tersebut adalah :

c) Peneliti akan berusaha membuat suasana nyaman dan membentuk keakraban lebih dalam dengan Siswa.

d) Peneliti akan mengkoordinasikan waktu dengan wali kelas dan guru mata pelajaran, sehingga jam bimbingan dan Siswang bisa digunakan semaksimal mungkin untuk rileksasi.

e) Peneliti akan menjelaskan tahapan dalam relaksasi dan memberikan mereka tips-tips agar mudah dalam melakukan relaksasi secara mandiri.

Hasil post-test I menunjukan bahwa adanya penurunan skor rata-rata dari pra-tindakan/pretest pada siklus pertama. Kemudian pada kategorisasi siswa sebelumnya tujuh orang siswa berada pada kategori tinggi mengalami penurunan menjadi rendah dan lima berada pada kategori sedang mengalami penurunan menjadi rendah. Ini membuktikan bahwa teknik tersebut mampu menurunkan kejenuhan belajar siswa, namun penurunan ini belum mencapai target yang ditentukan yaitu minimal 70\% siswa berada pada kategori rendah. Maka dari itu perlu adanya tindakan berikutnya untuk mencapai target yang telah ditentukan. 


\section{b) Tindakan Siklus II}

Hasil dari tindakan pada siklus kedua dalam penelitian ini dapat dilihat dari pengamatan dan post-test II. Pemberian post-test II dilaksanakan setelah seminggu setelah kegiatan tindakan 2. Data kejenuhan belajar siswa setelah dilakukan post test II dari 28 siswa, skor teringgi adalah 140 dan skor terendah adalah 82. Berdasarkan hasil post test II sudah menunjukan adanya penurunan hasil dibandingkan dengan post test I . Skor rata rata yang dicapai siswa dalam kategori rendah yaitu 96,71. Penurunan skor kejenuhan belajar dari pre-test hingga post test II. Hal tersebut menunjukan terdapat tujuh siswa yang memiliki kategori sedang setelah siklus II,. Selain tingkat penurunan rata-rata skor mulai dari pre-test hingga post-test II juga ditunjukkan dalam garfik sebagai berikut :

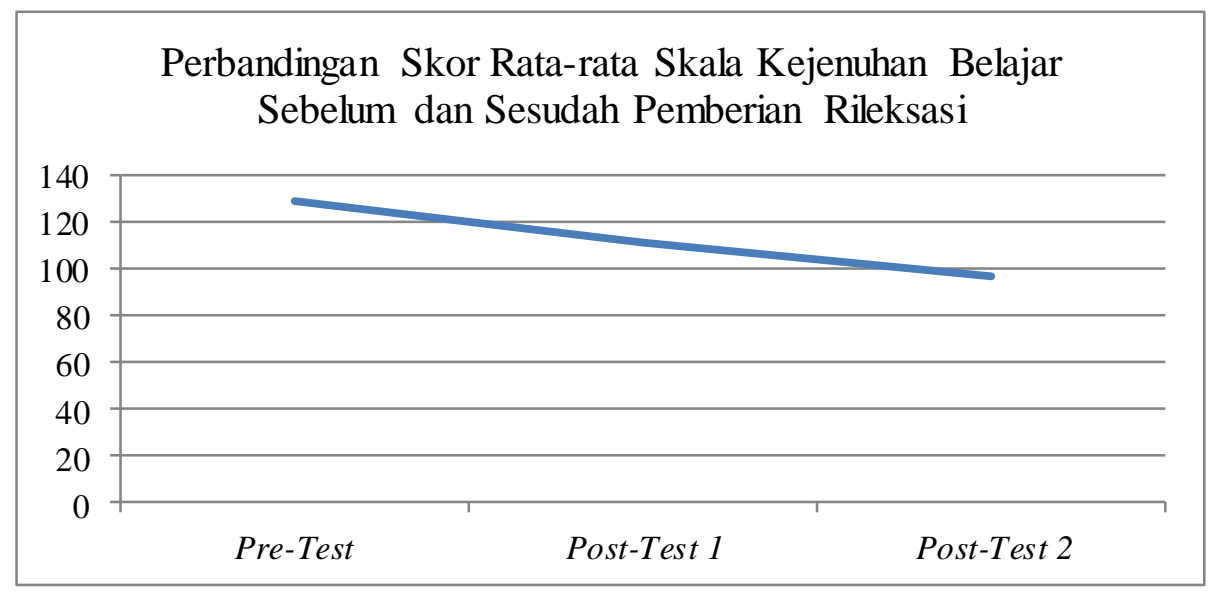

Grafik 1. Skor Rata-rata Skala Kejenuhan Belajar

Grafik 1 menunjukan skor rata-rata kejenuhan belajar siswa mengalami penurunan dari 128,75 poin pada pre-test menjadi 111,67 poin pada post-test I, dan 96,71 poin postest II. Skor tersebut merupakan skor rata-rata kejenuhan belajar secara keseluruhan, berikut grafik jumlah siswa dalam setiap kategori:

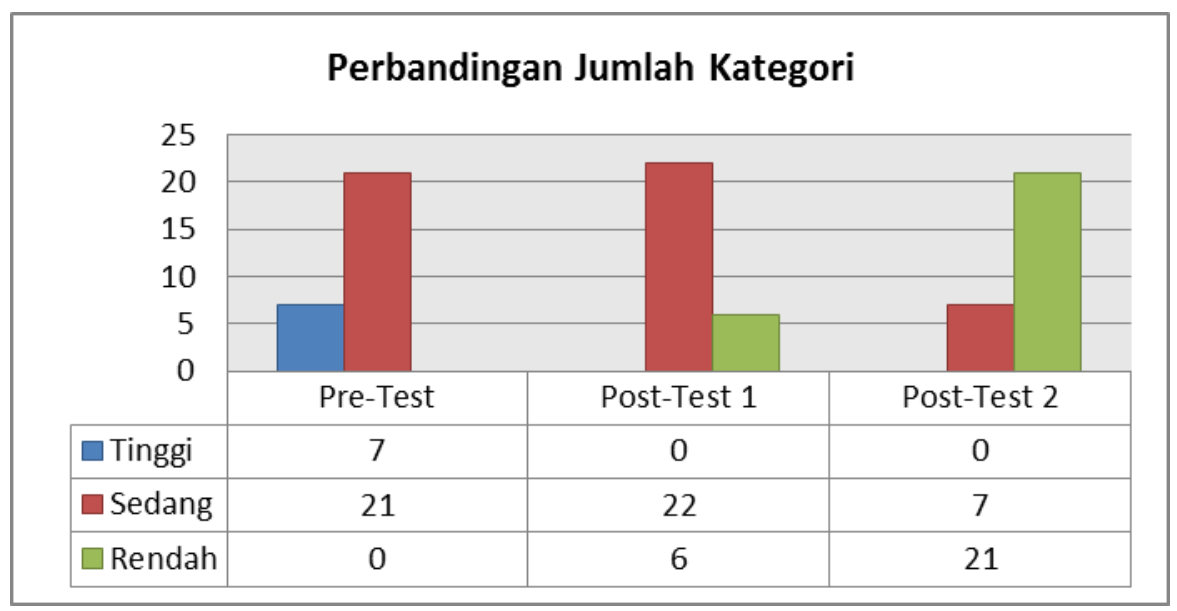

Grafik 2. Perbandingan Jumlah Kategori pada Setiap Test 
Grafik 2 menunjukkan terdapat perubahan jumlah pada tiap tes. Pada pre-test sebanyak tujuh siswa masuk dalam kategori tinggi, 21 siswa dalam kategori sedang dan tidak terdapat siswa yang kejeunhan belajarnya masuk dalam kategori rendah. Pada Posttest I tidak terdapat siswa yang skor kejenuhan belajarnya masuk dalam kategori tinggi, 22 siswa masuk dalam ketegori sedang dan enam siswa dalam kategori rendah. Pada Post-test II tidak terdapat siswa yang skor kejenuhan belajarnya masuk dalam ketegori tinggi, tujuh siswa masuk dalam kategori sedang dan 21 siswa dalam kategori rendah.

Berdasarkan grafik 2, pada siklus II jumlah siswa yang masuk dalam ketegori rendah adalah 21 siswa dari 28 siswa. Jika dipresentasekan maka 75\% siswa/subjek skor kejenuhan belajarnya telah masuk dalam kategori rendah. Dengan demikian peneliti memutuskan untuk tidak mengadakan siklus lanjutan karena penelitian ini sudah memenuhi kriteria keberhasilan yang terlah ditentukan yaitu $70 \%$ siswa skor kejenuhan belajarnya telah berada dalam kategori rendah.

\section{Hasil Self Report}

Berdasarkan hasil dari self report, peneliti memperoleh informasi bahwa rata-rata siswa melaksanakan relaksasi otot secara mandiri 4 kali dalam jangka waktu 8 hari. Setelah melaksanakan relaksasi otot siswa merasakan perubahan bahwa siswa lebih relaks, senang, nyaman, lelah dan mengantuk. Sedangkan kejadian-kejadian yang dialami siswa kebanyakan tidak diisi oleh siswa, sehingga peneliti menyimpulkan bahwa dalam kurun waktu 8 hari kondisi psikologis siswa stabil.

\section{Hasil Pengamatan (Observing)}

Hasil observasi dan pelaksanaan relaksasi untuk menurunkan kejenuhan belajar adalah sebagai berikut : Pada pertemuan 1 sudah sesuai dengan keinginan konselor, ini terlihat dari antusias Siswa dan mereka sudah tidak canggung melainkan sudah sangat santai. Pada saat pelaksanaan rileksasi siswa merespon arahan dari peneliti dengan baik. Sebagian besar Siswa terlihat tidak sabar untuk segera memulai rileksasi. Berbeda dengan siklus sebelumnya, kali ini sebagian besar siswa terlihat berpartisipasi dengan baik. Proses bimbingan dan rileksasi pada tindakan kali ini berjalan dengan sangat baik. Observasi juga dilakukan peneliti ketika siswa sedang mengikuti pelajaran di kelas. Peneliti melakukan pengamatan pada beberapa subjek dari beberapa kelas terlihat mengikut pelajaran dengan baik. Namun ada beberapa siswa ketika diamati terlihat pasif di kelas.

\section{Hasil Refleksi}

Tindakan pada siklus II menunjukan adanya perubahan jika dibandingkan dengan tindakan pada siklus I. Evaluasi dari siklus I dapat dikatakan berhasil dilaksanakan pada siklus II.

\section{PEMBAHASAN}

Setelah dilaksanakan dua kali siklus diperoleh hasil bahwa kejenuhan belajar siswa kelas VIII MTs Negeri 1 Kota Makassar mengalami penurunan. Penurunan tersebut dapat dilihat dari rata-rata skor pre-test sebesar 128,75 turun menjadi 111,67 pada post-test I dan kembali turun setelah siklus kedua dengan skor rata-rata post-test II sebesar 96,71. Hal ini menunjukkan adanya penurunan skor rata-rata kejenuhan belajar dari sebelum tindakan 
(pre-test) hingga dilakukannya post-test II dengan skor sebesar 32,03. Kemudian dari data 28 siswa menunjukan bahwa sebelum diadakan tindakan terdapat tujuh siswa yang skor kejenuhan belajarnya berada pada kategori tinggi dan 21 siswa berada pada kategori sedang. Setelah diadakan siklus I didapatkan hasil yaitu 22 siswa skor kejenuhan belajarnya berada pada kategori sedang dan enam siswa berada pada kategori rendah. Selanjutnya setelah diadakan siklus II terjadi penurunan kembali yang ditunjukkan dengan 21 siswa skor kejenuhan belajarnya berada pada kategori rendah dan tujuh siswa skor kejenuhan belajarnya berada pada kategori sedang. Dari hasil siklus kedua menunjukan bahwa kejenuhan belajar siswa kelas VIII MTs Negeri 1 Kota Makassar mengalami penurunan.

Penelitian ini membuktikan bahwa bimbingan kelompok teknik relaksasi dapat menurunkan kejenuhan belajar. Relaksasi merupakan suatu teknik yang dapat digunakan semua orang untuk menciptakan mekanisme batin dalam diri seseorang dengan membentuk pribadi yang baik, menghilangkan berbagai bentuk pikiran yang kacau akibat ketidakberdayaan seseorang dalam mengendalikan stress dan emosi yang dimilikinya, mempermudah seseorang mengontrol diri, menyelamatkan jiwa dan membersihkan kesehatan dan kecantikan tubuh, hal tersebut sesuai dengan pendapat Hakim (2004) bahwa salah satu cara mengatasi kejenuhan belajar adalah dengan melakukan relaksasi maupun aktivitas rekreasi atau hiburan. IPt. Edi Sutarjo, Dewi Arum WMP. \& Ni. Kt. Suarni (2014:55), berpandangan pula bahwa burnout yang dialami siswa dapat dikondisikan atau dapat diminimalisasi dengan tingkah laku yaitu dengan menggunakan teknik relaksasi serta dapat pula membantu meringankan kondisi tegang atau jenuh yang dialami oleh siswa. Menurut Syah (2003: 180) penyebab kejenuhan yang paling umum adalah keletihan yang melanda, karena keletihan dapat menjadi penyebab munculnya perasaan bosan pada sisiwa yang bersangkutan. Keletihan sendiri adalah keadaan tubuh yang tidak berdaya karena baru saja melakukan kegiatan yang berat dan sebagainya, maka perlu direlaksasi atau penyegaran kembali.

Berdasarkan pendapat diatas dapat disimpulkan bahwa keletihan yang menjadi penyebab kejenuhan belajar siswa dapat diatasi dengan teknik relaksasi. Dalam kegiatan bimbingan kelompok teknik relaksasi juga dilaksanakan diskusi, melalui diskusi siswa dapat saling bekerja sama dalam memecahkan masalah kejenuhan belajar. Sesuai dengan pendapat Tohirin (2007: 271) yang menjelaskan bahwa kegiatan diskusi merupakan suatu cara di mana siswa memperoleh kesempatan untuk memecahkan masalah secara bersamasama karena setiap siswa yang terlibat dalam diskusi kelompok merasa terbantu oleh teman sebayanya. Setelah dilaksanakan bimbingan kelompok teknik relaksasi, kejenuhan belajar siswa berkurang. Berdasarkan hasil post-test II, sebanyak 21 atau $75 \%$ dari 28 siswa skor kejenuhan belajarnya berada pada kategori rendah. Hal ini telah memenuhi keriteria keberhasilan penelitian yaitu $70 \%$ subjek skor kejenuhan belajarnya berada pada kategori rendah.

\section{SIMPULAN}

Berdasarkan hasil penelitian diperoleh bahwa tingkat kejenuhan belajar siswa di MTs Negeri 1 Kota Makassar pada kondisi awal umumnya berada pada ketegori sangat 
tinggi. Setelah pelaksanaan relaksasi dalam bimbingan kelompok menunjukkan adanya perubahan yang cukup signifikan. Pada siklus I kecenderungan umum kejenuhan belajar siswa berada pada kategori tinggi. Kemudian pada siklus II terjadi penurunan tingkat kejenuhan belajar ke kategori rendah. Relaksasi otot efektif untuk menurunkan tingkat kejenuhan belajar pada siswa kelas VIII di MTs N 1 Kota Makassar. Dibuktikan dengan hasil perbandingan Pretest dan Protest yang menunjukan adanya penurunan signifikan dari kejenuhan belajar konseli. Disamping itu teknik relaksasi dalam bimbingan kelompok dapat menurunkan kejenuhan belajar siswa. Artinya, apabila teknik relaksasi dalam bimbingan kelompok ini diterapkan maka dapat membantu menurunkan kejenuhan belajar siswa kelas VIII di MTs Negeri 1 Kota Makassar.

\section{DAFTAR PUSTAKA}

Chamid, A. \& Rochmanudin. (2011). Lulus smp/mts ?. Yogyakarta: Paramitha Publishing.

Hakim, T. (2004). Belajar secara efektif. Jakarta: Pustaka Pembangunan Swadaya Nusantara.

IPt. Edi Sutarjo, Dewi Arum WMP., Ni. Kt. Suarni. (2014). "Efektifitas teori Behavioral Teknik Relaksasi dan Brain Gym untuk Menurukan Burnout Belajar pada Siswa Kelas VIII SMP Laboratorium UNDIKSHA Sigaraja Tahun Pelajaran 2013/ 2014". E-journal Undiksa. Volume: 2 No 1. Diakses dari http//ejournal.undiksha.ac.id/index.php/JJBK/article/viewFile/3740/2995. Pada 12 Februari 2019 pukul 11.05 WITA.

Johana E. Prawitasari. (1988). Laporan penelitian pengaruh relaksasi tarhadap keluhan fisik: suatu studi eksperimental. Yogyakarta: Fakultas Psikologi UGM.

Monks, F. J. dkk. 2014. Psikologi perkembangan, pengantar dalam berbagai bagiannya cetakan ketujuh belas. Yogyakarta: Gadjah Mada University Press.

Muna, N.R. (2013). Efektifitas teknik self regulation learning dalam mereduksi tingkat kejenuhan belajar siswa di sma insan cindekiasekarkemuning cirebon. Jurnal Holistik Vol 14 No. 02.

Sugihartono, dkk. (2012). Psikologi pendidikan. Yogyakarta: UNY Press.

Suwarjo \& Eliasa, E. I. (2013). 55 permainan dalam bimbingan dan konseling cetakan keenam. Yogyakarta: Paramitra Publishing.

Syah, M. (2003). Psikologi belajar. Jakarta: PT Raja Grafindo Persada.

Tohirin. (2009). Bimbingan dan konseling di sekolah dan madrasah (berbasis integrasi). Jakarta: Rajawali Press.

Zuni Eka K. \& Elisabeth Christiana. (2014). Penerapan Kombinasi antara Teknik Relaksasi dan Self-Intruction untuk Mengurangi Kejenuhan Belajar Siswa Kelas XI IPA 2 SMA Negeri 22 Surabaya. Jurnal BK UNESA, 05(01), 1-10. 